\title{
Krzysztof Abriszewski
}

Uniwersytet Mikołaja Kopernika w Toruniu

ORCID: 0000-0003-1467-6936

\section{Adrian Zabielski}

Uniwersytet Mikołaja Kopernika w Toruniu

ORCID: 0000-0003-0047-1593

$29 / 2020$

Political Dialogues

DOI: http:/ /dx.doi.org/10.12775/DP.2020.017

\section{Niewiedza, cynizm i zniechęcenie. Trzy fazy nowoczesności i ich formy ideologiczne}

\begin{abstract}
:
The first part of the paper follows Shoshana Zuboff The Age of Surveillance Capitalism and presents three stages of Modernity. The third stage, surveillance capitalism itself, is then expanded with Nick Srnicek's concept of platform capitalism. The second part of the paper interprets Slavoj Žižek's traditional / cynical ideology distinction as a kind of historical sequence. Subsequently, we propose the third form of ideology that relies on post-truth. We argue that three stages of Modernity match three dominant forms of ideology. Juxtaposed together they may help to form a matrix containing stages of modernity, forms of ideology and subject responses. In the final paragraphs we argue that such a matrix is a good resource to analyze critical potential of popcultural artifacts.
\end{abstract}

Keywords: Modernity, ideology, surveillance capitalism, platform capitalism, subject

Słowa kluczowe: nowoczesność, ideologia, kapitalizm inwigilacyjny, kapitalizm platformowy, przedmiot

W ostatnich latach badacze reprezentujący różne dyscypliny humanistyczne i społeczne wkładają wiele wysiłku w uchwycenie specyfiki współczesności kładąc większy nacisk raz na kryzys kapitalizmu, innym razem na kryzys ekologiczny, przeobrażenia technologiczne, czy jeszcze inne procesy. W istocie, prac tego rodzaju w ostatnich kilkunastu latach powstało tak wiele, że nie sposób już się w nich dobrze rozeznać. W pełni jednak zgadzamy się z przenikającym te próby założeniem, że osiągnęliśmy szczególny, nowy moment nowoczesności, który wymaga świeżego myślowego uchwycenia i być może nowych narzędzi teoretycznych. Analitycznie, moglibyśmy wyodrębnić, nieco sztucz- 
nie zapewne, trzy ważne nurty przenikające ten napływ publikacji: (1) prace starające się uchwycić najważniejsze zmiany i nową rzeczywistość z perspektywy systemowej; (2) prace koncentrujące się na sytuacji, kształcie i sprawczości współczesnych podmiotów; (3) prace intencjonalnie wpisujące się w tradycję krytyczną. Oczywiście, wiele z tych publikacji w jakiejś mierze lokuje się więcej niż w jednym z tak wyodrębnionych nurtów.

W niniejszym artykule nie mamy ambicji, by posunąć do przodu rozważania w zakresie któregoś z tych nurtów. Naszym celem jest raczej wybiórcze skorzystanie z ich wybranych rezultatów i stworzenie pewnych powiązań między nimi, tworząc połączenie między nurtami. Dokładniej rzecz biorąc, chcielibyśmy sięgnąć do głośnej w ostatnim czasie książki Shoshany Zuboff The Age of Surveillance Capitalism ${ }^{1}$ i zrekonstruować za nią trzy etapy nowoczesności. Jej uwagi o trzeciej nowoczesności uzupełnimy korzystając z innych autorów, przede wszystkim zaś z pracy Nicka Srnicka Platform Capitalism ${ }^{2}$. Do tak stworzonej quasi historycznej sekwencji chcielibyśmy przyłożyć dwie formy ideologii wielokrotnie omawiane przez słoweńskiego filozofa Slavoja Žižka, przede wszystkim w książce Wzniosty obiekt ideologii³. Te dwie formy chcemy zinterpretować również historycznie, a następnie uzupełnić o trzecią, do której opisu wykorzystamy uwagi Paula

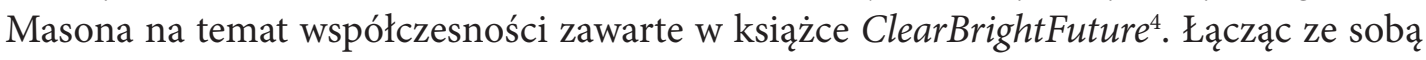
te dwie sekwencje: „fazy” nowoczesności z formami ideologii tak, że każdemu stadium nowoczesności będzie odpowiadała dominująca forma ideologiczna, stworzymy matrycę, która naszym zdaniem może pomóc uporządkować problemy związane z pracą krytyczną wymierzaną przeciw konkretnej ideologii i na rzecz poprawy określonej formy porządku społecznego. Przede wszystkim zaś mamy nadzieję, że tak skonstruowana matryca pomoże w analizie dzieł, zjawisk, zdarzeń i procesów w jak najszerzej rozumianej kulturze popularnej z uwagi na ich (przypuszczalny) krytyczny potencjał.

Tekst zasadniczy dzielimy na trzy części. Najpierw omówimy w podstawowym zakresie trzy stadia nowoczesności, później poszerzymy jeszcze ujęcie stadium ostatniego o koncepcję kapitalizmu platform, zaś w trzecim kroku przejdziemy do kwestii form ideologicznych. W niniejszym artykule posługujemy się pojęciem „nowoczesności” i traktujemy je tutaj jako nadrzędne i najszersze w stosunku do innych pokrewnych, czy konkurencyjnych. Czynimy tak jednak dla uporządkowania wywodu i jeśli czytelniczka lub czytelnik wolałby potraktować jako nadrzędną kategorię np. „kapitalizmu” lub „antropocenu", to zasadniczo nie uważamy tego za problem, a co najwyżej za przesunięcie akcentów. Kłopot oczywiście leży w tym, że przywoływani przez nas autorzy i autorki też

${ }^{1}$ Zuboff, Shoshana, The Age of Surveillance Capitalism: The Fight for a Human Nature at the new Frontier of Power, NowyJork: Public Affairs 2018.

2 Srnicek, Nick, Platform Capitalism, Cambridge: Polity Presss 2017.

3 Žižek, Slavoj, Wzniosły obiekt ideologii, przekł. J. Bator i P. Dybel, Wrocław: Wydawnictwo Uniwersytetu Wrocławskiego 2001.

${ }^{4}$ Mason, Paul, Clear Bright Future. A Radical Defence of the Human Being, Allen Lane, Penguin Books, 2019. 
mają swoje preferencje, jedni wolą mówić o nowoczesności, inni o kapitalizmie, jeszcze zaś inni podkreślają, że znajdujemy się w przestrzeni społecznej po kapitalizmie. Nie chcąc wdawać się w dyskusję wokół tych różnic, chociaż pamiętając o nich, wybieramy jedną kategorię stosunkowo najdogodniejszą w tym miejscu dla naszych rozważań.

\section{Trzy nowoczesności}

Pod koniec ostatniej dekady XX wieku miało miejsce wydarzenie o bezprecedensowym charakterze. Stworzona przez człowieka sztuczna inteligencja odpaliła głowice jądrowe w kierunku największych miast świata, dokonując ogromnych zniszczeń i pozbawiając życia miliardy ludzi. Wydarzenie to, znane historii jako Dzień Sądu, rozpoczęło niekończący się konflikt między ludźmi i maszynami. Obie strony tego konfliktu z czasem opracowywały coraz skuteczniejsze metody eliminacji jednostek przeciwnika, jednak prawdziwym przełomem było wynalezienie sposobu na podróżowanie w czasie. Od tego momentu rzeczywistość zaczęła się rozgałęziać, pojawiły się alternatywne daty Dnia Sądu, a wojna z wrogiem nabrała nowego wymiaru - orężem stało się przekształcenie wszystkich wariantów przyszłości na niekorzyść wroga, co w praktyce stało się nieosiągalne. Każda korekta przeszłości przypominała bowiem ucięcie łba hydrze, wywołując szereg niedających się przewidzieć konsekwencji. Jeżeli mielibyśmy wyciągać jakieś lekcje ze świata Terminatora, to być może te o nieigraniu ze sztuczną inteligencją oraz niemożności posiadania całkowitej kontroli w społeczeństwie kształtowanym przez technonaukę.

Terminator pojawia się w tym kontekście także z innych powodów. W uniwersum filmowym Skynet jest nazwą superkomputera, zbudowanego przez korporację Cyberdyne w oparciu o szczątki robotów-terminatorów przybyłych z przyszłości. Maszyna ta staje się zarzewiem sztucznej inteligencji - tej, która zainicjowała Dzień Sądu. W świecie realnym Skynet ${ }^{5}$ jest stosowanym przez chiński rząd informatycznym systemem rozpoznawania i śledzenia ludzi, obejmującym swoim zasięgiem cały kraj. Oficjalnie system ten służy zapewnieniu bezpieczeństwa obywatelom i jest tak zaawansowany, że można za jego pomocą przewidzieć kto, kiedy i gdzie popełni przestępstwo, a następnie temu zapobiec. Jednym z elementów tego systemu są algorytmy rozpoznawania twarzy, opra-

${ }^{5}$ Zbieżność nazw nie jest przypadkowa. XieYinan, wiceprezes Megvii Technology, jedej z firm współpracujących przy chińskim projekcie Skynet przyznał, że Terminator jest ulubionym filmem założyciela firmy. Stwierdził jednak, że w przeciwieństwie do filmowego pierwowzoru realny Skynet ,jest dobry”, a przyszłością jest rzeczywistość przypominająca tę z odcinka serialu Black Mirror zatytułowanego Nosedive. Już teraz znajduje ona odzwierciedlenie w tak zwanym Systemie zaufania społecznego (Social Credit System), gdzie każdemu obywatelowi przyznawane i odbierane są punkty za pożądane lub niepożądane zachowania określane przez władzę. Od stanu punktowego osoby zależy jej dostęp do korzystania z usług oferowanych przez społeczeństwo, takich jak kredyty, czy podróże. Zob. Vice, Battle for Jerusalem \& A Face In The Crowd, [odcinekserialudokumentalnego], USA, 2018. 
cowywane przez firmę SenseNets ${ }^{6}$. Umożliwiają one identyfikację tożsamości w czasie rzeczywistym, gromadząc przy tym inne dane na temat śledzonych osób, od temperatury ich ciał, przez noszone przez nie ubrania, po ich rodzinne i przyjacielskie koneksje. Jak się okazało w lutym 2019 roku dostęp do tych danych był niedostatecznie zabezpieczony, co umożliwiło wyciek informacji na temat 2,5 miliona osób do Internetu? Większość spośród nich stanowiły dane dotyczące członków muzułmańskiej mniejszości Ujgurów, która jest represjonowana przez chiński rząd. Co więcej, technologie rozpoznawania twarzy wykorzystywane były również wobec protestujących w Hong Kongu , którzy dość szybko nauczyli się zakrywać i zamalowywać twarze w taki sposób, by oszukiwać śledzące ich algorytmy.

Istnieje podejrzenie, że podobne metody znalazły zastosowanie podczas demonstracji w Stanach Zjednoczonych po zamordowaniu George'a Floyda ${ }^{9}$, i to pomimo wsparcia protestów przez największe firmy z branży technologicznej. Wyraziły one konieczność legislacyjnego unormowania technologii inwigilacyjnych przed ich wdrażaniem ${ }^{10}$. Dodatkowo okazuje się, że dla algorytmów „uczących się” rozpoznawania twarzy wzorcowym wizerunkiem jest biały mężczyzna, co powoduje niezliczone błędy w identyfikacji potencjalnych podejrzanych o innej płci i kolorze skóry ${ }^{11}$. Technologia ta zatem nie tylko ingeruje w prywatne życie obywateli, ale jest również wadliwa i urasowiona.

Przywołanie powyższych wydarzeń, zjawisk i tropów kultury popularnej ma na celu zarysowanie osi podziału władzy, których kształtowanie dostrzec można obecnie, a które jeszcze zyskają na znaczeniu po przeprowadzeniu pandemicznej terapii szokowej. Mamy tu zatem aspekt technologiczno-inwigilacyjny, w którym władza określana jest na podstawie dostępu do informacji i możliwości ich gromadzenia pod postacią danych; mamy oś przebiegającą między tym co państwowe i tym co korporacyjne, gdzie tendencje autorytarne splatają się lub krzyżują z prywatnymi interesami cyfrowych gigantów, oraz aspekty biopolityczne, z których najbardziej wyraziste są kwestie płciowe, rasowe oraz

6 Tao, Li, „SenseNets: the facial recognition company that supplies China's Skynet surveillance system”, 12 kwietnia 2019, https://www.scmp.com/tech/science-research/article/3005733/what-you-need-knowabout-sensenets-facial-recognition-firm, dostęp: 29.06.2020.

7 Tamże.

${ }^{8}$ Mozur, Paul, „In Hong Kong Protests, Faces Become Weapons”, [online], 26 lipca 2019, https:// www.nytimes.com/2019/07/26/technology/hong-kong-protests-facial-recognition-surveillance.html, dostęp: 29.06.2020.

9 Reichert, Corinne, „Senator fears Clearview AI facial recognition could be used on protesters”, $8 \mathrm{cz}$ erwca 2020, https://www.cnet.com/news/senator-concerned-clearview-ai-facial-recognition-is-being-usedby-police-in-black-lives-matter-protests, dostęp: 29.06.2020.

${ }^{10}$ Fowler, Geoffrey A., „Black Lives Matter could change facial recognition forever - If Big Tech doesn't stand in the way", 12 czerwca 2020, https://www.washingtonpost.com/technology/2020/06/12/facial-recognition-ban, dostęp: 29.06.2020.

${ }^{11}$ Lohr, Steve, „Facial Recognition Is Accurate, if You're a White Guy”, [online], 9 lutego 2018, https:// www.nytimes.com/2018/02/09/technology/facial-recognition-race-artificial-intelligence.html, [dostęp: 29.06.2020]. 
funkcjonowanie w rzeczywistości postpandemicznej, czyli regulowanie życia z uwzględnieniem wszechobecności niewidzialnego zagrożenia.

Jak znaleźliśmy się w takim momencie historycznym? Interesującym tropem jest historia cyfrowej transformacji nowoczesności, opisana przez ShoshanęZuboff w pracyThe Age ofSurveillanceCapitalism ${ }^{12}$. Kapitalizm nadzoru, jak nazywa swój model Zuboff, jest formacją, w której władza określana jest na podstawie dostępu do informacji gromadzonych jako dane. Dane te otrzymywane są drogą ekstrakcji nadwyżki behawioralnej (behavioralsurplus) - pochodzą z udostępnianych przez ludzi treści oraz analizy zachowań dokonywanej przez algorytmy na podstawie informacji przesyłanych sieciowo z urządzeń elektronicznych. Następnie służą one celom komercyjnym, są odsprzedawane firmom i agencjom rządowym, stają się podstawą wytwarzania kapitału oraz narzędzi kontroli i nadzoru. Tę nową formę władzy Zuboff nazywa instrumentarianizmem.

Zanim jednak wyłonił się kapitalizm nadzoru nowoczesność ewoluowała w trzech etapach. Pierwszą fazę nowoczesności otworzyło wynalezienie sposobu na masową produkcję dóbr na początku XX wieku, co w następstwie umożliwiło ich masową konsumpcję. Taśma produkcyjna i rozpowszechnienie fordyzmu w zarządzaniu zmieniły nie tylko sposób wytwarzania i pozyskiwania przedmiotów codziennego użytku, ale także to jak funkcjonowało wykorzystujące je społeczeństwo. Uwaga ludzi skierowana została na ich własne, jednostkowe życia, nadano im istotność, godność, podczas gdy wcześniej centrum optyki stanowiło przetrwanie klanów i rodzin. Te ostatnie zyskały rolę „fabryk osobowości" - miejsc reprodukcji siły roboczej, których zadaniem było przystosowywanie ludzi do życia w społeczeństwie. Sensem życia stało się bycie produktywnym, co wiązało się z dopasowywaniem, lub nawet wypieraniem jaźni zgodnie z potrzebami społeczeństwa. Efektem umasowienia był rozrost biurokracji, ale ułatwiło to wytwarzanie indywidualnego bogactwa oraz dodało dynamiki procesom demokratyzacyjnym, co przełożyło się na takie zjawiska jak upowszechnienie edukacji, czy ochrony zdrowia.

Przejście z pierwszego do drugiego etapu modernizacji charakteryzowały dwa wektory. Pierwszym z nich było przekształcenie trybu produkcji z masowego na indywidualny, drugim: zyskanie na globalnym znaczeniu neoliberalizmu jako odpowiedzi na kryzys stagflacji w latach 70. XX wieku. Wolny rynek wraz ze swoją „niewidzialną ręką” został wówczas zaprezentowany jako atrakcyjna alternatywa dla kolektywizmu i totalitaryzmu. Ujawniło się pęknięcie z pierwszego etapu nowoczesności, między indywidualnymi aspiracjami jednostek, a represyjnym charakterem społeczeństwa masowego. Naturalność rozwarstwień społecznych i nierówności praw, będące elementami ideologii neoliberalnej, stały się podwalinami pod funkcjonowanie współczesnych korporacji. Ich zyskiwanie na znaczeniu osłabiło procesy demokratyzacji, co w efekcie przypominającym sprzężenie zwrotne tylko wzmocniło neoliberalne tendencje w krajach Zachodu. Początkowo głównym wrogiem był komunizm, ale gdy przestał stanowić zagrożenie,

${ }^{12}$ Sh. Zuboff, The Age of Surveillance Capitalism.... 
stało się nim państwo wraz z podatkami i regulacjami ograniczającymi swobodę działalności gospodarczej.

Drugą nowoczesność charakteryzuje, według Zuboff, upowszechnienie typu osobowości, który określić można jako neoliberalny narcyzm. Centralnym punktem zainteresowania stała się indywidualistycznakonsumpcja. Nie bez znaczenia było tu masowe usieciowienie społeczeństwa. Umożliwiło ono natychmiastową komunikację, błyskawiczny przesył informacji i takąż samą konsumpcję. Zgodnie $\mathrm{z}$ ideologią neoliberalną funkcjonował przekaz, że nie ma społeczeństwa, są tylko jednostki, które muszą nieustannie renegocjować relacje między sobą. Samoświadomość stała się centralnym punktem zainteresowania człowieka, co wiązało się z koniecznością indywidualnego nadawania sensu życia. Paradoksalnie miało to także skutek dyscyplinujący, bowiem ludzie samotnie konkurujący z innymi o zasoby są zbyt zajęci walką o przetrwanie, by kontestować dominującą ideologię.

Efektem ograniczania roli państwa i zrzucenia odpowiedzialności za dobrostan na jednostki był brak stabilności finansowej, marginalizacja oraz wykluczenie osób, które nie mogły lub nie chciały uczestniczyć w realizacji założeń neoliberalizmu. Charakterystyczne dla drugiej modernizacji było powszechne występowanie poczucia beznadziei, której źródło tkwiło w ekstremalnych nierównościach, przy jednoczesnym dynamicznym rozwoju sfery cyfrowej i Internetu. Zdaniem Zuboff neoliberalizm osłabił demokrację i światową gospodarkę, czyniąc je wrażliwymi na kryzysy ekonomiczne i społeczne. Reprezentanci tego nurtu, inspirowani przez takie postaci jak Ronald Reagan i Margaret Thatcher, rozmontowali postulowany przez Polanyiego ruch dwukierunkowy, w myśl którego zadaniem państwa jest ograniczanie destruktywnych tendencji rynku. Nastąpiło odejście od publicznego i zwrócenie się ku prywatnemu, rozwinął się kult przedsiębiorczości, a miejsce produkcji i zaspokajania potrzeb jako celu gospodarki zajęły spekulacja i zadowalanie akcjonariuszy.

Zuboff pisze za Pikettym ${ }^{13}$ i innymi badaczami społecznymi, że ekonomia rynkowa musi być trzymana w ryzach przez mechanizmy demokratyczne, ponieważ kapitalizm puszczony samopas jest antyspołeczny i prowadzi do skrajnych rozwarstwień, a w ostateczności do neofeudalizmu. Współczesne mechanizmy rynkowe zaczynają przypominać te z czasów przedkapitalistycznych, jednak jednocześnie ludzie i świat są już inni, bardziej świadomi tego jak ważna jest wolność, są lepiej wyedukowani i odżywieni, niż feudalni chłopi. Zuboff zakłada optymistycznie, że od tego nie ma już odwrotu. Występuje konflikt między rosnącą świadomością dotyczącą sfery wolności, a ograniczaniem tejże przez mechanizmy rynkowe, co prowadzi do poczucia niesprawiedliwości i wybuchów niezadowolenia, takich jak ruch Occupy. To napięcie i jednoczesny rozstrzał

${ }^{13}$ Piketty, Thomas, Kapitat w XXI wieku, tłum. Andrzej Bilik, Warszawa: Wydawnictwo Krytyki Politycznej 2015. 
między osobistymi aspiracjami jednostek, a ograniczeniem możliwości ich realizacji historycznie stanowiło preludium trzeciej nowoczesności.

Władza korporacji cyfrowych wyłoniła się w tej właśnie przestrzeni, umożliwiając ludziom samorealizację za cenę, na którą ich stać. Efektem jest wszechobecność spersonalizowanych, tanich urządzeń elektronicznych, aplikacji i usług. Za możliwością powszechnego konsumowania kryją się jednak praktyki znane z drugiej nowoczesności, takie jak windowanie cen, przenoszenie produkcji do krajów o niskich kosztach pracy, wyzysk, czy unikanie opodatkowania. Według Zuboff obietnica emancypacji niesiona przez trzecią nowoczesność obarczona jest zatem częściowo sprzecznościami drugiej nowoczesności, dochodzi jednak tu do mutacji, wykształcania cech osobniczych. Jedną z nich jest erozja prywatności - można się spodziewać, że informacje raz udostępnione w Internecie zostają w nim już na zawsze i będą wykorzystane do wytwarzania kapitału w zupełnie niespodziewanych miejscach.

Wspomniana już możliwość konsumpcji uniewrażliwiła ludzi na mechanizmy przejmowania władzy, które mają miejsce w samym sercu kapitalizmu nadzoru - w korporacjach cyfrowych, stojących za wytwarzaniem urządzeń elektronicznych i gromadzeniem danych. Użytkownicy wyrażają zgodę na ich praktyki kiedy zakładają konta na serwisach online, kilkoma kliknięciami potwierdzając jednostronną gotowość do wypełniania ścisłych warunków nienegocjowalnych umów. Przeczytanie i zrozumienie ich bez specjalistycznego wykształcenia oraz dużych ilości wolnego czasu jest niemożliwe, a w każdej chwili mogą one ulec zmianie. Instrumentalne i wirtualne wykorzystanie prawa i kontraktu jako formy zrzekania się swobód prowadzi do erozji tych rozwiązań w innych sferach życia, tracą one swoją wagę i znaczenie. Prawdopodobnie nie jest to jednak usuwalna wada wynikająca z młodego wieku trzeciej nowoczesności, lecz jej nieodłączna cecha, nie cena modernizacji, lecz efekt postępowania zgodnie z jej logiką.

Zuboff za Josephem Schumpeterem wskazuje, że „mutacje” kapitalizmu potrzebują czasu, by wywołać efekt długoterminowy. Utrwalanie dokonuje się przez instytucjonalizację, poprzedzoną okresem prób i błędów, tworzenia i niszczenia, rozłożonego na dziesięcio-, a nawet i stulecia, którego finałem jest poprawienie losu wszystkich ludzi. Kult błyskawicznego postępu za wszelką cenę uprawiany w Krzemowej Dolinie nie pozwala na utrwalanie instytucjonalne, przez co, przykładowo, prawo powszechne nie nadąża za rozwojem technologicznym. Można stwierdzić, że w modelu Zuboff trzecia nowoczesność przejmuje i potęguje jedną z cech drugiej nowoczesności, czyli brak stabilności, stojąc w sprzeczności z ideą „racjonalnego kapitalizmu”, postulowaną przez Schumpetera. Jeżeli miał on rację, to być może należałoby spojrzeć dalej w przeszłość, celem odnalezienia początków długotrwałych procesów, których obecnym etapem jest trzecia faza modernizacji.

W kapitalizmie nadzoru zanik prywatności stał się ceną, którą ludzie ponoszą za powszechny dostęp do „darmowych” treści. Emancypacyjna obietnica nieograniczonego dostępu do informacji niesiona przez wczesne lata globalnego usieciowiania zosta- 
ła przekuta w formę władzy i ekonomicznej zależności, w unikatowy mechanizm akumulacji, oparty na pozyskiwaniu nadwyżki behawioralnej. Nie jest to jednak aberracja, a konsekwencja procesów modernizacyjnych zachodzących od początków kapitalizmu, najpierw w jego umasowionej, a następnie sprywatyzowanej postaci. Według Zuboff walka toczy się o jakość indywidualnego życia, będącą podstawą funkcjonowania w społeczeństwie demokratycznym - o prawo do samostanowienia, do posiadania kontroli nad własną przyszłością (right to the futuretense), do sanktuarium. Miałoby się to odbywać przez redukcję asymetrii między użytkownikami, a dysponentami władzy w kapitalizmie nadzoru. Czy można jednak kontestować tę formę władzy wyłącznie w jej ramach, bez odniesienia się do ideologicznych podwalin, które tchnęły w nią życie? By umożliwić odpowiedź na to pytanie przyjrzymy się formom ideologicznym funkcjonującym na poszczególnych etapach modernizacji, jednak zanim to nastąpi proponujemy poszerzyć wywód Zuboff, zwłaszcza część poświęconą trzeciej nowoczesności, odwołując się do jednej z prób krytycznego ujęcia współczesności, którestworzy pewną przeciwwagę dla jej teoriomodernizacyjnego optymizmu.

\section{Platformy}

Pośród prób uchwycenia szczególnego charakteru współczesności z ambicjami antycypowania tego, co nadejdzie, znajduje się ciekawa koncepcja Nicka Srnicka, który mówi o kapitalizmie platform ${ }^{14}$. Na poziomie założeń idzie tą samą ścieżką, którą podążała kilka lat temu ważna i głośna książka Jasona Moore’aCapitalism in the Web of Life ${ }^{15}$ oraz jego inne prace ${ }^{16}$, w których starał się on spojrzeć na kapitalizm przez pryzmat trzech kluczowych, splatających się kategorii: kryzysów, granic oraz CheapNatures ${ }^{17}$ - tanich zasobów naturalnych. Pozyskiwanie, przetwarzanie oraz obrót tanimi zasobami naturalnymi są systemowo kluczowe, ale ich wyczerpywanie się bezwzględne (ich całkowite zużycie) oraz względne (gdy robi się ich zbyt mało dla procesów społecznych, które one podtrzymują lub stają się dla nich zbyt kosztowne) wywołuje kryzys. Moore mówi o dwóch typach kryzysów: rozwojowym i systemowym. Ten drugi doprowadza do upadku systemu, który nie potrafi sobie z nim poradzić. Kryzys rozwojowy zaś po okresie zapaści zostaje przezwyciężony przez przesunięcie którejś z systemowych granic. Zmienia to sytuację i prowadzi do rozwoju systemu ${ }^{18}$.

${ }^{14}$ N. Srnicek, Platform Capitalism.

${ }_{15}$ Moore, Jason, Capitalism in the Web of Life. Ecology and the Accumulation of Capital, London, New York: Verso 2015.

${ }_{16}$ Zob. np. Patel, Raj i Moore, Jason, A History of the World in Seven Cheap Things. A Guide to Capitalism, Nature, and the Future of the Planet, London, New York: Verso 2018.

17 „Naturalny” nie musi oznaczać w tym przypadku, „przyrodniczy” zgodnie ze złożoną ontologią proponowaną przez Moore’a. Do CheapNatures, czyli tanich zasobów naturalnych Moore zalicza: siłę roboczą, żywność, energię i surowce pierwotne (J. Moore, Capitalism..., s. 17).

${ }_{18}$ Moore mówi raczej o kapitalizmie oraz o kapitałocenie (jako epoce kapitału), systemie, systemie-świe- 
Srnicek nie powołuje się na Moore’a, ale ten świetnie pasuje jako punkt wyjścia do rozważań o kapitalizmie platform. Otóż, Srnicek kreśli nieco szerszą panoramę rozwoju obejmując znaczną część wieku XX i początek XXI, by postawić tezę, że współczesna faza kapitalizmu jako tani zasób naturalny (czyli Cheap Nature) odkryła dane. Istniały one oczywiście wcześniej i bywały pozyskiwane, ale, jak zaznacza, stare modele prowadzenia interesów nie były skonstruowane w taki sposób, aby je zdobywać, rejestrować i wykorzystywać ${ }^{19}$. Przywodzi to na myśl schematy kolistego obrotu danymi behawioralnymi po ich pozyskaniu i z późniejszym zwrotnym zastosowaniu, które zamieściła w swojej książce Zuboff ${ }^{20}$.

W obecnej fazie nowoczesności, którą, jak zostało już powiedziane, Srnicek nazywa kapitalizmem platform ${ }^{21}$, operowaniem danymi jako surowcami pierwotnymi zajmują się nowe formy instytucjonalne, czy też organizacyjne - być może z uwagi na ich złożony charakter najwygodniej byłoby określić je deleuzjańskim mianem asamblaży - nazwane właśnie platformami. Badacz ów tak je charakteryzuje:

„Czym są platformy? Na najbardziej ogólnym poziomie, platformy są cyfrowymi infrastrukturami, które umożliwiają interakcję dwu lub więcej grup. Tym samym, sytuują siebie jako pośredników łączących różnych użytkowników: klientów, reklamodawców, usługodawców, producentów, dostarczycieli [dóbr], a nawet fizyczne przedmioty. Raczej częściej niż rzadziej, platformy te zapewniają serię narzędzi pozwalających ich użytkownikom na tworzenie własnych produktów, usług i rynków"22.

Platformy mogą uzyskać przewagę nad starymi formami organizacyjnymi i odnieść sukces dzięki temu, że nie budują rynków od podstaw, korzystając z już istniejących, ale za to oferują infrastrukturę, która stanowi środowisko pośredniczące między różnymi aktorami ${ }^{23}$. Patrząc z innej perspektywy, jeśli posłużymy się starym Gombrowiczowskim określeniem tego, co międzyludzkie, to platformy są właśnie tym międzyludzkim - jednocześnie pośrednikiem i formą pośredniczenia. Lub - by posłużyć się jeszcze starszą ontologią George’a Berkeleya - są Berkeleyowskim Bogiem, czy też Umysłem (koniecznie z wielkich liter $)^{24}$, to znaczy jednocześnie mają swoją odrębną tożsamość - są firmami, które mają swoje nazwy, loga i którym trzeba płacić za usługi - oraz środowiskiem,

cie, czy ekologii-świecie, ponieważ jednak w niniejszym artykule raczej posługujemy się pojęciem nowoczesności jako nadrzędnym, dlatego też wykorzystujemy je w tym miejscu przywołując rozważania Moore’a.

19 N. Srnicek, Platform Capitalism, s. 32-33.

${ }^{20}$ Zob. S. Zuboff, The Age of Surveillance Capitalism..., ryc. 2, s. 100.Posługiwaliśmy się wydaniem cyfrowym książki w formacie epub, numeracja stron może różnić się od wydania papierowego.

${ }^{21}$ N. Srnicek, Platform Capitalism.

22 Tamże, s. 33-34.Posługiwaliśmy się wydaniem cyfrowym książki w formacie epub, numeracja stron może różnić się od wydania papierowego.

${ }^{23}$ Tamże, s. 34.

${ }_{24}$ Berkeley, George. 1956. Traktat o zasadach poznania. Trzy dialogi, tłum. Jan Leszczyński i Janina Sosnowska, Warszawa: Państwowe Wydawnictwo Naukowe. 
w którym umysły (z małej litery), czyli ludzie mogą działać, przestrzenią obiektywizacji, czy też stabilizowania się tego, co subiektywne.

Platformy bazują na zasadzie sieci, im więcej użytkowników, tym sieć potężniejsza, ale też tym bardziej wartościowa staje się ona dla jeszcze-nie-użytkowników ${ }^{25}$. Aby udało się gładko wciągać tych ostatnich, platformy stosują złożone zabiegi polegające na działaniu ze stratą w jednym obszarze i oferowaniu usług bardzo tanich albo darmowych po to, by odzyskać swoje zyski gdzie indziej ${ }^{26}$. Platformy takie, jak Google, czy Facebook mogą oferować darmowe konta po to, by przyciągnąć tych, od których pozyskają nadwyżkę behawioralną, dzięki której będą najważniejszymi graczami na rynku reklam. Platformy oferujące usługi streamingowe mogą oferować darmowe konta z ograniczeniami i reklamami po to, by albo zarobić na reklamach, albo na tyle zachęcić użytkownika do usługi i zniechęcić do niewygód, by ten wykupił płatną wersję usług.

Srnicek wyróżnia pięć typów platform ${ }^{27}$ zaznaczając, że oczywiście jest to podział analityczny, który pozwala uporządkować materiał, ale w praktyce rzeczywiste platformy często łączą różne formy lub przechodzą między nimi. Są to: 1. platformy reklamujące, które nie operują żadnymi produktami, są jedynie infrastrukturami kontaktu między aktorami społecznymi, co pozwala na pozyskiwanie danych behawioralnych. Te z kolei po opracowaniu stanowią podstawę do sprzedawania przestrzeni reklamowej. Najważniejsze takie platformy do oczywiście Google i Facebook. 2. Platformy-chmury, które wynajmują stosowne oprogramowanie i miejsce do operowania nim, jak i składowania danych. Toteż posiadając określoną infrastrukturę oraz software sprzedają one pewną usługę, jeśli słowo to będziemy pojmowali szeroko. 3. Platformy przemysłowe, które nową formułę organizacyjną adaptują do przekształcania przemysłu znanego nam z wcześniejszych faz nowoczesności w przemysł połączony i nadzorowany za pomocą internetu, co wpływa znacząco na organizację i koszty pracy. 4 Platformy oferujące pewien produkt. Przykładem, który najszybciej przychodzi na myśl są popularne platformy streamingowe, które za opłatą (abonamentową, jednorazową itd.) umożliwiają dostęp do muzyki, filmów, książek i innych produktów. 5. Ostatnim typem są platformy, które Srnicek określa po angielsku jako lean, czyli „nachylające się”, albo może lepiej „naciągające”. Są to asamblaże, które usiłują stosować platformowy model jako sposób organizacji pewnego obszaru społecznego, czy też obszaru gospodarki, przy jednoczesnym jak najdalej idącym wycofaniu jakiegokolwiek materialnego zaangażowania w ten obszar, co charakteryzowało tradycyjne formy działania. Przykładami są choćby Uber, czy Airbnb. Tradycyjne taksówki najpierw stwarzały całą infrastrukturę - samochody, profesjonalni kierowcy, formy koordynowania działań, szkolenia, sprzęt etc. - by za jej pomocą reorganizować pewien wycinek świata społecznego. Uber stara się zrobić to samo, ale bez

\footnotetext{
25 N. Srnicek, Platform Capitalism, s. 34.

26 Tamże, s. 35.

27 Tamże, s. 36-55.
} 
całej tej infrastruktury, a jedynie za pomocą platformowej formy organizacji „nachylić”, czy też „naciągnąç” kierowców normalnie jeżdżących po danym obszarze, by zrobili coś trochę więcej, tzn. zabrali pasażera i go przewieźli w pożądane miejsce. Zysk z założenia ma pochodzić $\mathrm{z}$ tego nachylenia lub naciągnięcia na to trochę więcej.

Wszystkie te platformy pozostają dynamiczne. Srnicek zwraca uwagę np., że platformy nachylające są głęboko niestabilne i nie przynoszą wystarczających zysków, a dodatkowo są wyniszczane wojnami z konkurencją. Podobne zmagania toczą platformy przemysłowe, które starają się budować monopol ${ }^{28}$. Szerokim echem odbijają się problemy platform oferujących produkty, jak np. oskarżanie Spotify o niewystarczające opłacanie artystów zapewniających treści dla serwisu, czy napięcia między Netflixem a tradycyjną branżą filmową opartą na kinach i festiwalach. Ta niestabilność oznacza, że niezależnie od aktualnego układu sił, jest on bardzo podatny na wszelkie destabilizacje.

\section{Ideologia}

Na teorię ideologii najczęściej patrzy się przez wpływową linię biegnącą od Karola Marksa, w której dobrą metaforą ideologii są okulary zniekształcające obraz rzeczywistości. Jednakże w XX wieku pojawiła się ważna jej odnoga, która znacząco się odróżniła, wprowadzając kilka kluczowych zmian. Linia ta obejmuje takich filozofów, jak Louis Althusser ${ }^{29}$ oraz SlavojŽižek ${ }^{30}$. Zwłaszcza ujęcie relacji między dwiema formami ideologii dokonane przez Žižka jest tu kluczowe ${ }^{31}$. Zanim pokrótce przypomnimy ujęcie zaproponowane przez słoweńskiego filozofa, zauważmy, że możemy w teorii ideologii wyróżnić trzy poziomy: (1) poziom treści ideologicznych - tego, jaki konkretnie przekaz ideologiczny działa w danym empirycznym przypadku; (2) poziom formy ideologii jaki mechanizm ideologiczny zostaje uruchomiony; (3) poziom ogólnej teorii ideologii. To ważne, ponieważ tradycyjnie często utożsamiane były dwa ostatnie. Ważny wkład Žižka polega na tym, że pomógł je zdecydowanie rozróżnić. Gdyby więc rozpocząć od najogólniejszego poziomu, to można odwołać się do następującej uwagi tego filozofa ze Wzniosłego obiektu ideologii:

„Rzeczywistym celem ideologii jest postawa, której ona wymaga, konsystencja formy ideologicznej, fakt, że kroczymy w miarę możności jak najprościej w tym samym kierunku. Pozy-

28 Tamże, s. 60-78.

${ }^{29}$ Althusser, Louis. 2017. „Ideologie i Aparaty Ideologiczne Państwa”, tłum. Andrzej Staroń, „Nowa Krytyka”, http://www.nowakrytyka.pl/pl/Ksiazki/Ksiazki_on-line/?id=888, dostęp: 2.07.2020.

${ }_{30}$ Przede wszystkim chodzi o dwie książki: S. Žižek, Wzniosły obiekt ideologii orazŽižek, Slavoj. 2001. Przekleństwo fantazji, tłum. Adam Chmielewski, Wrocław: Wydawnictwo Uniwersytetu Wrocławskiego; zob. także ważną pracę redagowaną przez słoweńskiego filozofa: MappingIdeology, S. Žižek (red.), London, New York: Verso, 1994.

31 Zob. np. S. Žižek, Wzniosty obiekt..., s. 42-44. 
tywne racje podawane przez ideologię w celu uzasadnienia tego wymogu (...) służą tylko ukrywaniu tego faktu"32.

Idąc tym tropem, ideologia jako pewne wydzielone zjawisko kulturowe byłaby złożonym mechanizmem komunikacyjnym, w którym ma zostać uzyskany cel wskazany w cytacie powyższym - „kroczymy w tym samym kierunku” - i dzieje się tak w wyniku operacji władzy. To bardzo pobieżne określenie czym jest ideologia w sensie najszerszym, jednak jest ono potrzebne, by wyróżnić trzy formy ideologii (mechanizmów ideologicznych) odpowiadające trzem fazom nowoczesności. Zacznijmy od dwóch form wskazanych przez Žižka.

Pierwsza, tradycyjna forma ideologii. Według niej, ideologia to dyskursywnie skonstruowany fałszywy, czy też zaburzony obraz rzeczywistości. Celem jego konstruowania jest sprawienie, by ci, na których oddziałuje zachowywali się w sposób pożądany, zwłaszcza zaś, by nie dążyli do przekształcenia istniejących relacji władzy. I tu możemy skorzystać z metafory okularów: zniekształcają one obraz rzeczywistości, ale dopóki nie zostaną zdjęte ci, którzy je noszą nie są tego świadomi. Žižek na opisanie sytuacji podmiotu, posługuje się tutaj marksowską formułą: „robią to, ale o tym nie wiedzą"33. To znaczy, że ideologia rozgrywa się w planie epistemologii - poddany ideologii podmiot nie posiada właściwej wiedzy.

Druga forma ideologii, którą rozwija Žižek idąc w ślady Althussera zostaje przez autora Przekleństwa fantazji określona jako „cyniczna” i opisuje ją formuła: „bardzo dobrze wiedzą, co robią, a mimo to nadal to robią" ${ }^{34}$. Argumentacja Žižka i Althussera mówi, że ideologia nie rozgrywa się na poziomie wiedzy (i niewiedzy), ale na poziomie działania. Kluczowe znaczenie ma tutaj ideologiczne pragnienie, które kształtuje sposób działania.

Prosty przykład pozwoli nakreślić różnicę między obiema formami. Według pierwszej formy ideologii, o tym, że np. wyzyskiwani pracownicy nie walczą o swoje prawa decyduje brak wiedzy np. o świecie społecznym i relacjach władzy. Rola ideologii polega na tym, że celowo podsuwa ona wiedzę fałszywie przedstawiającą rzeczywistość. Typowym przykładem drugiej formy będzie np. świadomość następującego rodzaju: „bardzo dobrze wiem, że elektroodpady przyczyniają się do degradacji środowiska, a handel koltanem wiąże się z konfliktami zbrojnymi i destabilizowaniem sytuacji w Kongo, niemniej lubię często zmieniać telefony komórkowe”. W tej formule ideologicznej, nie ma żadnego istotnego powiązania między wiedzą na temat sytuacji, a działaniem podejmowanym przez podmiot. Nieistotne powiązanie mogłoby jedynie polegać na próbach samousprawiedliwiania, np. „wiem, że tam się źle dzieje, ale jak jedna osoba kupi nowy telefon, to i tak to nic nie zmieni".

\footnotetext{
32 Tamże, s. 105.

33 Tamże, s. 42.

34 Tamże, s. 44.
} 
Te dwie formy możemy potraktować odrębnie, kreśląc równolegle dla nich dwie teorie ideologii. Ale możemy też próbować ująć jako dwa odmienne typy ideologii, które historycznie następują po sobie. Powszechna niewiedza i mechanizmy ideologiczne ją utrzymujące (ideologia rozumiana epistemologicznie) możemy schematycznie potraktować jako dominujące w pierwszej nowoczesności opisanej za Zuboff. Charakterystycznym sposobem walki z tą formą ideologii byłyby wszelkie inicjatywy samokształcenia się robotników tak powszechne w wieku XIX i w części XX.

Drugą nowoczesność, jak wiemy od Zuboff, charakteryzuje wypieranie mechanizmów homogenicznej kultury masowej przez kulturę indywidualizacji. Zwróćmy uwagę, że Zuboff brzmi nadzwyczaj optymistycznie, gdy mówi o zmianach w środkach służących do budowania udanego życia. Bardziej krytyczne podejścia, od Szkoły Frankfurckiej, przez studia kulturowe aż po przywoływanego Žižka, będą mówiły o kulturze konsumpcyjnej. I takie właśnie powiązanie czyni słoweński filozof: cyniczna forma ideologii charakteryzuje kapitalistyczną kulturę konsumpcji. To, co u Zuboff wygląda na pozytywną ścieżkę ludzkiej samorealizacji, w ujęciach krytycznych jest systemowo skonstruowanym szaleństwem konsumowania.

Jednak wyróżniliśmy za Zuboff trzy fazy nowoczesności, należałoby więc teraz zapytać, jaka forma ideologiczna byłaby charakterystyczna dla fazy trzeciej. Zaznaczmy najpierw, że mówiąc o historycznym następstwie nie mamy na myśli całkowitego wypierania jednej formy ideologicznej przez drugą, ale przesunięcia w proporcjach między nimi. Tym samym stawiając tezę o ideologii trzeciej nowoczesności dalekonam, by sugerować, że pozostałe dwie formuły zniknęły, bo tak się z pewnością nie stało. Aby określić na czym może polegać trzecia forma ideologii odwołamy się do Paula Masona.

W swojej książce ClearBrightFuture ${ }^{35}$ również przywołuje ten euforyczny z perspektywy indywidualizującego się podmiotu, ${ }^{36}$ moment związany z rozpoznaniem możliwości cyfrowych mediów sieciowych, ale czyni to w kontekście ruchów polityczno-emancypacyjnych. Pisze tak:

„W 2011 roku, w euforii wywołanej Arabską Wiosną i ruchami Occupy, mogło się zdawać, że usieciowiona komunikacja w jednej chwili była w stanie obalić całą propagandę. Rządy utraciły moc kontrolowania obrazu wojny i konfliktu; oficjalną wersję wydarzeń można było zweryfikować w czasie rzeczywistym dzięki świadkom będącym na miejscu. Prawicowe i autorytarne rządy były w stanie przetrwać dzięki wytwarzaniu bańki informacyjnej wokół swych zwolenników, lecz to nigdy nie wystarczyło do uzyskania społecznego przyzwolenia (consent) ${ }^{37}$.

${ }^{35}$ Mason, Paul, Clear....

${ }^{36}$ Zuboff czyni rozróżnienie na indywidualizację - uwolnienie potencjału jednostek jako długotrwały efekt modernizacji, indywidualizm - separację jednostki od pozostałych ludzi, będącą elementem ideologii neoliberalnej, oraz indywiduację, która w jej modelu zajmuje miejsce samorozwoju. Zob. Sh.Zuboff, The Age of Surveillance Capitalism..., s. 37.

37 Paul Mason, Clear..., s. 93. 
Nie trwało to jednak długo. Wyraźnie widać, jak media sieciowe poradziły sobie bez problemu z sytuacją charakterystyczną dla pierwszej z opisanych form ideologicznych: fałszywego obrazu świata. Możliwość weryfikacji, a zwłaszcza, w czasie rzeczywistym, oczami (obiektywami) zwykłych uczestników danych zdarzeń jeśli nawet nie uniemożliwia, to utrudnia funkcjonowanie ideologii jako zakłóconego obrazu świata. W przypadku przywoływanych przez Masona wydarzeń, również ideologia cyniczna, pasująca do rzeczywistości kultury konsumpcyjnej, nie nadawała się do zmagań z ruchami protestu społecznego. Jak dalej pisze Mason:

„Częściowym rozwiązaniem stały się fake newsy: prokurowanie historii jawnie nieprawdziwych. Inną częścią tej strategii było zapoczątkowane w Rosji zaśmiecanie sieci tak olbrzymią ilością dezinformacji i nadużyć, że ludzi to od niej odrzucało. Do 2013 roku rosyjskie „brygady sieciowe" - młodzi ludzie pracujący na "farmach trolli” - wprawili się w zatruwaniu atmosfery każdego forum dyskusyjnego" ${ }^{38}$.

Zjawiska takie, jak postprawda, fake newsy, armie płatnych internetowych trolli, czy boty i fikcyjne konta służące do wpływania na rzeczywistość sieci oraz inne pokrewne powinniśmy zatem potraktować nie jako np. zbrutalizowaną mutację starych form ideologicznych, ale jako nowe fenomeny, których cel jest identyczny jak w przypadku tych pierwszych, ale w nowej rzeczywistości kulturowej - w trzeciej nowoczesności, nowoczesności platform i nadzoru.

Paul Mason konkluduje swoje uwagi w tym miejscu, spoglądając szerzej:

„Ważne jest, by zrozumieć, jak trolle, boty i twórcy fake newsów działają razem jako system. Ich celem nie jest przekonanie innych, że ich wersja rzeczywistości jest prawdziwa; chodzi o sprawienie, że atmosfera debat politycznych w sieci będzie tak agresywna i nieprzyjemna, że zwykli ludzie będą ich unikać; także o stworzenie wrażenia, że wszystkie strony są zaangażowane w wojnę propagandową, a zatem żadne informacje nie są wiarygodne"39.

O ile więc mechanizm pierwszej formy ideologicznej opierał się na wytworzeniu fałszywego obrazu świata poprzez rozpowszechnianie fikcyjnych opowieści, a drugiej na wytwarzaniu takiej dynamiki pragnienia, aby świadomość prawdy niczego nie zmieniała, tak trzecia forma ideologii poprzez konstruowanie toksycznego środowiska stara się wywołać poczucie zniechęcenia i bezcelowości jakichkolwiek działań i dociekań. Nie chce ani wpływać na wiedzę (pierwsza forma), ani na pragnienie (druga forma), a na stany emocjonalne, zasypać komunikacyjnymi śmieciami jakąkolwiek wolę działania. Za pionierów tego rodzaju działań ideologicznych należy uznać tzw. handlarzy zwątpieniem, czyli wszystkich tych, którzy zajmowali się celowym zaciemnianiem faktów i wy-

\footnotetext{
38 Tamże, s. 93.

39 P. Mason, Clear..., s. 93.
} 
woływaniem powątpiewaniaw odniesieniu do takich ustaleń naukowych na temat szkodliwości palenia papierosów czy ludzkich działań wywołujących kryzysy ekologiczne, co przedstawili w klasycznej pracy Merchants of Doubt Naomi Oreskes i Eric M.Conway ${ }^{40}$.

Patrząc z tej perspektywy, widać jak na dłoni, jaką mrzonką filozoficzną jest uparte trzymanie się pomysłu, że z wszelkimi formami nieprawdy należy walczyć za pomocą analizy treści wypowiedzi ${ }^{41}$. Trzecia forma ideologiczna wcale nie ukrywa, że jej treści są fałszywe, głupie i zmyślone. Trolle nie argumentują, boty nie wchodzą w quasi sokratejskie dialogi, wytwarzają jedynie szum informacyjny i emocjonalny. Tradycyjne środki filozoficzne nie oferują wcale sposobu walki z szumem.

Gdyby zaś wrócić do ideologicznych formuł Žižka, to można teraz zestawić trzy takie formuły - dwie przywołując za nim, trzecią zaś dodając do nich: formuła pierwszego typu ideologii mówiła „robią to, ale o tym nie wiedzą”. Formuła druga, cyniczna mówiła: „bardzo dobrze wiedzą, co robią, a mimo to nadal to robią”. Zaś trzecią formułę ideologii z jej postprawdą i śmieciami informacyjnymi można wyobrazić sobie na przykład tak: „nie robią nic, bo mają poczucie bezsensu robienia czegokolwiek”.

Skonkludujmy dla jasności: celem trzeciej formy ideologicznej nie jest wytworzenie fałszywego obrazu, bo generuje mrowie jawnie głupich i nonsensownych przekazów. Dąży ona do wywołania poczucia zniechęcenia, obojętności, .wrażenia, że wszyscy i wszystko jest takie samo, nic nie warte. Nikt nie walczy o sprawę czy wartości, każdy realizuje własne, przyziemne interesy. Zwróćmy uwagę, że w ten sposób trzecia formuła ideologiczna chętnie wykorzystuje krytyczny schemat, który miał służyć do walki z ideologią pierwszego rodzaju (krytyka fikcji przekazu przez ujawnienie ukrytych za nią interesów). Tym samym, ideologia w tej chwili może przedstawiać się jako myślenie krytyczne. W najgorszej formie, może nawet przekonywać do takiego „krytycznego” działania. Reakcją na tę sytuację jest oczywiście wycofanie, „emigracja wewnętrzna”, zajęcie się swoimi sprawami, w których nie ma miejsca na „brudne rozgrywki i interesy".

Możemy teraz wywód na temat faz nowoczesności i dominujących w nich form ideologicznych podsumować $\mathrm{w}$ formie tabeli:

Tabela 1. Zestawienie cech poszczególnych faz nowoczesności z odpowiadającymi im dominującymi formami ideologii oraz głównymi efektami podmiotowymi.

\begin{tabular}{|l|l|l|l|}
\hline \multicolumn{1}{|c|}{ Faza nowoczesności } & \multicolumn{1}{|c|}{ Cechy nowoczesności } & \multicolumn{1}{c|}{ Ideologia } & Pożądany stan podmiotu \\
\hline 1 & $\begin{array}{l}\text { Masy, kultura masowa, } \\
\text { przemysł }\end{array}$ & $\begin{array}{l}\text { Epistemologia - znie- } \\
\text { kształcona wiedza }\end{array}$ & Niewiedza \\
\hline
\end{tabular}

${ }^{40}$ Oreskes, Naomi i Conway, Eric M., Merchants of Doubt. How a Handful of Scientists Obscured the Truth on Issues from Tobacco Smoke to Global Warming, New York, Berlin, London: Bloomsbury Press 2010.

${ }^{41} \mathrm{~W}$ ostatnim czasie, świetnie wykazał to Andrzej W. Nowak w recenzji książki Światy równoległe Łukasza Lamży, Andrzej. W Nowak, „Chrońcie naukę od takich przyjaciół”, http://czaskultury.pl/czytanki/ chroncie-nauke-od-takich-przyjaciol/, dostęp 2.07.2020. 
Tabela 1. Zestawienie cech poszczególnych faz nowoczesności z odpowiadającymi im dominującymi formami ideologii oraz głównymi efektami podmiotowymi.

\begin{tabular}{|c|c|c|c|}
\hline Faza nowoczesności & Cechy nowoczesności & Ideologia & Pożądany stan podmiotu \\
\hline 2 & $\begin{array}{l}\text { Indywidualizacja, kon- } \\
\text { sumpcjonizm, upodmio- } \\
\text { towienie }\end{array}$ & Cyniczna & Pobudzone pragnienie \\
\hline 3 & $\begin{array}{l}\text { Kapitalizm nadzoru, } \\
\text { asymetria komunikacyj- } \\
\text { na, ekstrakcja nadwyżki } \\
\text { behawioralnej }\end{array}$ & Postprawda i fake newsy & Zniechęcenie, rezygnacja \\
\hline
\end{tabular}

\section{Podsumowanie: matryca, krytyka i dalsze badania}

Powyżej w Tabeli 1 zestawiamy ze sobą trzy fazy nowoczesności, trzy formy ideologiczne oraz trzy stany podmiotu, które ma wywołać oddziaływanie ideologii po to, by uzyskać określone działanie ze strony podmiotu. Warto przypomnieć, że jednym z kluczowych rozszerzeń, jakie do teorii ideologii wprowadziła linia Althusser-Žižek było odejście od pojmowania jej wyłącznie w kategoriach wiedzy na rzecz działania, jakie podmiot podejmuje. Dlatego też ostatnia kolumna, która przedstawia reakcje podmiotowe, jest tak zróżnicowana.

Tabela ta stanowi oczywiście uproszczenie w stosunku do fenomenów, które możemy zaobserwować w świecie społecznym. Ale o to właśnie chodzi, jest ona matrycą, która może pomóc w analizie zjawisk. Może ona również pomóc w podjęciu pytania o formy krytyki społecznej, ponieważ pozwala poszerzyć perspektywę i wyjść poza myślenie o krytyce w oparciu o schemat ujawniania niejawnej prawdy, który stanowi po prostu odwrotność epistemologicznej (pierwszej) formy ideologicznej. Okazuje się on jednak dramatycznie nieskuteczny przeciw cynicznej, czy zniechęcającej formie ideologii i wtedy musi zostać wsparty lub zastąpiony przez inne formy krytyki.

Jak wskazywaliśmy na wstępie, jesteśmy również przekonani, że matrycę powyższą można wykorzystać do analizy zjawisk i dzieł kultury popularnej, dzięki czemu lepiej zrozumiemy ich nasycenie krytyczne. Dla ilustracji weźmy dwa głośne w niedawnym czasie przykłady filmów, o których potencjale krytycznym szeroko dyskutowano. Jeden z nich to Joker ${ }^{42}$, drugi do Parasite ${ }^{43}$, oba z 2019 roku. Jak ona jednak wygląda z perspektywy naszego schematu?

Joker przedstawia trajektorię życiową Arthura Flecka, który przechodząc przez kolejne etapy rozczarowań i rozpaczy staje się na końcu tytułowym superzłoczyńcą. Ta nowa tożsamość właściwie tylko zamyka opowieść, a przez większość filmu śledzimy smutne, poruszające losy Arthura. Z perspektywy naszej matrycy, jako jednostka zniechęcona i zrezygnowana reprezentuje trzeci, najpóźniejszy typ reakcji podmiotowej.

\footnotetext{
42 Joker, reż. Todd Phillips, 2019.

${ }^{43}$ Parasite, reż. Joon-ho Bong, 2019.
} 
O tyle, zrozumiałe może się wydawać, dlaczego wielu komentatorów uznało film za krytyczny obraz naszych czasów. Jednakże przesuwając się w naszej tabeli w lewą stronę, widzimy wyraźnie, że nowoczesność, którą oglądamy w filmie zdecydowanie nie jest w trzeciej fazie, a co najwyżej w drugiej, dla której charakterystyczne były procesy indywidualizacyjne, co pasuje również do artystycznych ambicji postaci Flecka - nie jest on częścią masy, do końca filmu pozostaje silnie wydzieloną jednostką.Jednocześnie jednak widzimy, że nie żyje on wcale w zagęszczonym informacyjnie środowisku trzeciej fazy nowoczesności. Toteż wydaje się, że ostrze krytyczne filmu jest wymierzone w to, do czego toksyczne otoczenie społeczne doprowadziło ułomną jednostkę, ale słabnie ono wyraźnie, gdy uświadomimy sobie, o jakich relacjachspołecznych mówi, bowiem tutaj co najwyżej przedstawia dobrze znane przeszłe obrazy,na przykład ukazując aroganckich bogaczy osobiście ingerujących w życie swych pracowników (Thomas Wayne i matka Arthura, PennyFleck).

Z kolei w Parasite wydaje się, że otrzymujemy krytykę relacji klasowych, łącznie $\mathrm{z}$ aktualną obserwacją wskazującą na brak solidarności klasowej w scenie, gdy podczas powodzi ktoś prosi o pomoc w wyprowadzeniu motocykla i nikt na to nie reaguje. W pędzie rodziny Gi do spełnienia wizji, by żyć jak bogacze, co jest wyraźne w scenie uroczystej kolacji w domu państwa Park, gdy ci wyjechali, widzimy realizację konsumpcyjnej podmiotowości. Jednocześnie silnie obecne media cyfrowe pełnią rolę środków skutecznego działania, udanej indywidualizacji i emancypacji: mogą pomóc sfałszować dokumenty, czy przełamać bariery klasowe gdy dwie osoby ślą do siebie sms-y. Nie są one jednak częścią rzeczywistości platform i w tym sensie, krytyczny wymiar Parasite mówi raczej o świecie, który już się zmienia. Tam, gdzie obserwujemy zachowania konsumpcjonistyczne, czy prekarną pracę (składanie opakowań do pizzy) rozpoznajemy naszą rzeczywistość społeczną, jednak tam, gdzie pojawiają się media cyfrowe uruchamia się nostalgiczny tryb tęsknoty za „dobrym” internetem z początku XXI wieku.

Mamy nadzieję, że te dwa bardzo skrótowo przywołane przykłady pokazują, że zaproponowana przez nas matryca nowoczesności i jej ideologii może stać się dogodnym narzędziem analitycznym. Jeśli tak jest, to pojawiają się kolejne ważne pytania: jakie formy krytyki odpowiadają każdemu z wierszy tabeli? Jakie relacje między jej polami możemy zaobserwować, zakładając, że nie tylko powiązania w obrębie poszczególnych poziomów tabeli? Czy są jakieś powiązania „zakazane”, permutacje niemożliwe do zrealizowania? Czy istnieją jakieś typy sprzężeń między odmiennymi rodzajami ideologii? 